\title{
Biodegradation of Used Motor Oil in Soil Using Organic Waste Amendments
}

\author{
O. P. Abioye, ${ }^{1,2}$ P. Agamuthu, ${ }^{1}$ and A. R. Abdul Aziz ${ }^{3}$ \\ ${ }^{1}$ Institute of Biological Sciences, University of Malaya, 50603 Kuala Lumpur, Malaysia \\ ${ }^{2}$ Department of Microbiology, Federal University of Technology, PMB 65, Minna 920281, Nigeria \\ ${ }^{3}$ Department of Chemical Engineering, University of Malaya, 50603 Kuala Lumpur, Malaysia
}

Correspondence should be addressed to O. P. Abioye, bisyem2603@yahoo.com

Received 6 March 2012; Revised 18 April 2012; Accepted 23 April 2012

Academic Editor: Goetz Laible

Copyright (C) 2012 O. P. Abioye et al. This is an open access article distributed under the Creative Commons Attribution License, which permits unrestricted use, distribution, and reproduction in any medium, provided the original work is properly cited.

\begin{abstract}
Soil and surface water contamination by used lubricating oil is a common occurrence in most developing countries. This has been shown to have harmful effects on the environment and human beings at large. Bioremediation can be an alternative green technology for remediation of such hydrocarbon-contaminated soil. Bioremediation of soil contaminated with 5\% and $15 \%$ (w/w) used lubricating oil and amended with $10 \%$ brewery spent grain (BSG), banana skin (BS), and spent mushroom compost (SMC) was studied for a period of 84 days, under laboratory condition. At the end of 84 days, the highest percentage of oil biodegradation (92\%) was recorded in soil contaminated with $5 \%$ used lubricating oil and amended with BSG, while only $55 \%$ of oil biodegradation was recorded in soil contaminated with $15 \%$ used lubricating oil and amended with BSG. Results of firstorder kinetic model to determine the rate of biodegradation of used lubricating oil revealed that soil amended with BSG recorded the highest rate of oil biodegradation $\left(0.4361 \mathrm{day}^{-1}\right)$ in $5 \%$ oil pollution, while BS amended soil recorded the highest rate of oil biodegradation $\left(0.0556 \mathrm{day}^{-1}\right)$ in $15 \%$ oil pollution. The results of this study demonstrated the potential of BSG as a good substrate for enhanced remediation of hydrocarbon contaminated soil at low pollution concentration.
\end{abstract}

\section{Introduction}

Contamination of soil by used lubricating oil is rapidly increasing due to global increase in the usage of petroleum products [1]. Environmental pollution with petroleum and petrochemical products has attracted much attention in recent decades. The presence of different types of automobiles and machinery has resulted in an increase in the use of lubricating oil. Spillage of used motor oils such as diesel or jet fuel contaminates our natural environment with hydrocarbon [2]. Hydrocarbon contamination of the air, soil, and freshwater especially by PAHs attracts public attention because many PAHs are toxic, mutagenic, and carcinogenic [3-5].

Prolonged exposure to high oil concentration may cause the development of liver or kidney disease, possible damage to the bone marrow, and an increased risk of cancer [68]. In addition, PAHs have a widespread occurrence in various ecosystems that contribute to the persistence of these compounds in the environment [9]. The illegal dumping of used motor oil is an environmental hazard with global ramifications [10]. Used motor oil contains metals and heavy polycyclic aromatic hydrocarbons (PAHs) that could contribute to chronic hazards including mutagenicity and carcinogenicity $[11,12]$.

Lack of essential nutrients such as nitrogen and phosphorus is one of the major factors affecting biodegradation of hydrocarbon by microorganisms in soil and water environment. Therefore, the addition of inorganic or organic nitrogen-rich nutrients (biostimulation) is an effective approach to enhance the bioremediation process [1315]. Positive effects of nitrogen amendment on microbial activity and/or petroleum hydrocarbon degradation have been widely demonstrated by various authors [16-19].

Concentration of petroleum hydrocarbon determines to a greater extent the rate of breakdown of the hydrocarbons from soil environment. High concentration of hydrocarbon can be inhibitory to microorganisms, and concentration at 
which inhibition occurs varied with the compound. Ijah and Antai [20] reported high degradation of hydrocarbons in soil contaminated with $10 \%$ and $20 \%$ crude oil compared to those contaminated with 30 and $40 \%$ crude oil which experienced partial degradation of hydrocarbons within a period of 12 months. Rahman et al. [21] reported that percentage of degradation by mixed bacterial consortium decreased from $78 \%$ to $52 \%$, as the concentration of crude oil increased from 1 to $10 \%$. High concentrations of hydrocarbons can be associated with heavy, undispersed oil slicks in water, causing inhibition of oil biodegradation due to oxygen limitation or through toxic effects exerted by volatile hydrocarbons on microorganisms.

The objectives of this study are to determine the potential of banana skin, brewery spent grain, and spent mushroom compost for enhanced biodegradation of used lubricating oil in soil, as an alternative to the use of inorganic fertilizers. These organic materials are widely available as wastes in our environment. The study also aimed to determine the effects of oil concentration on biodegradation of used lubricating oil.

\section{Methods}

2.1. Collection of Samples. The soil sample used was collected from the Nursery Section of the Asia-European Institute, University of Malaya, Kuala Lumpur, Malaysia, in a sack and transported to the laboratory for analysis. Used lubricating oil was collected from the Perodua Car Service Centre, Petaling Jaya, while the organic wastes were collected from different locations; banana skins (BS) were collected from the IPS Canteen, University of Malaya, brewery spent grains (BSG) were collected from Carlsberg Brewery, Shah Alam, Selangor, and spent mushroom compost (SMC) was the collected from Gano Mushroom Farm, Tanjung Sepat, Selangor.

2.2. Bioremediation Setup. $1.5 \mathrm{~kg}$ of soil (sieved with $2 \mathrm{~mm}$ mesh size) was placed in plastic vessels with a volume of about $3000 \mathrm{~cm}^{3}$, and $5 \%$ and $15 \%(\mathrm{w} / \mathrm{w})$ used lubricating oil was added separately, thoroughly mixed, and left undisturbed for 48 hours to allow the volatilization of toxic components of the oil. After two days, $10 \%$ of each organic waste (ground dry banana skin (BS), brewery spent grain (BSG), and spent mushroom compost (SMC)) were individually introduced into each oil-polluted soil and thoroughly mixed. The moisture was adjusted to $60 \%$ water holding capacity and incubated at room temperature $\left(28 \pm 2^{\circ} \mathrm{C}\right)$. Treatment with only soil and used lubricating oil served as control. Additional control was also set up which contained autoclaved soil poisoned with $0.5 \%(\mathrm{w} / \mathrm{w})$ sodium azide to monitor nonbiological loss of oil in the oil-contaminated soil. The content of each vessel was tilled twice a week for aeration and the moisture maintained at $60 \%$ water holding capacity by the addition of sterile distilled water. The experiment was set up in triplicate. Periodic sampling from each vessel was carried out at 14-day intervals for 84 days. Composite samples were obtained by mixing $5 \mathrm{~g}$ of soil collected from four different areas of the plastic vessels for isolation and enumeration of hydrocarbon utilizing bacteria and determination of total petroleum hydrocarbon.

\subsection{Physicochemical Analysis of Soil and Organic Wastes.} Nitrogen contents of soil used for bioremediation and organic wastes were determined using the Kjeldahl method, while phosphorus and carbon contents were determined using ICP-QES and furnace method, respectively. $\mathrm{pH}$ was determined with $\mathrm{pH}$ meter (HANNA HI 8424) on $1: 2.5$ $(\mathrm{w} / \mathrm{v})$ soil/distilled water after 30 minute equilibration. Triplicate determinations were made.

\subsection{Total Petroleum Hydrocarbon (TPH) Determination.} Residual hydrocarbon contents of the soil samples were determined by toluene cold extraction method of Adesodun and Mbagwu [22]. $10 \mathrm{~g}$ of soil sample was weighed into $50 \mathrm{~mL}$ flask, and $20 \mathrm{~mL}$ of toluene (AnalaR grade) added. After shaking for 30 minutes on an orbital shaker (model NBiotek-101M), the liquid phase of the extract was measured at $420 \mathrm{~nm}$ using DR/4000 Spectrophotometer. The total petroleum hydrocarbon (TPH) in soil was estimated with reference to a standard curve derived from fresh used lubricating oil diluted with toluene. TPH data were fitted to the first-order kinetics model:

$$
C=C_{o} e^{-k t},
$$

where $C$ is the hydrocarbon content in soil $\left(\mathrm{g} \mathrm{kg}^{-1}\right)$ at time $t$, $C_{o}$ is the initial hydrocarbon content in soil $\left(\mathrm{g} \mathrm{kg}^{-1}\right), k$ is the biodegradation rate constant $\left(\mathrm{d}^{-1}\right)$, and $t$ is time (d).

\subsection{Enumeration and Identification of Bacteria. Three repli-} cate samples from each oil-polluted soil were withdrawn every 14 days for the enumeration of hydrocarbon utilizing bacteria (HUB). $0.1 \mathrm{~mL}$ of serially diluted samples were plated on oil agar prepared from mineral salt medium of Zajic and Supplisson [23] $\left(1.8 \mathrm{~g} \mathrm{~K}_{2} \mathrm{HPO}_{4}, 4.0 \mathrm{~g} \mathrm{NH} \mathrm{NH}_{4} \mathrm{Cl}\right.$, $0.2 \mathrm{~g} \mathrm{MgSO}_{4} \cdot 7 \mathrm{H}_{2} \mathrm{O}, 1.2 \mathrm{~g} \mathrm{KH}_{2} \mathrm{PO}_{4}, 0.01 \mathrm{~g} \mathrm{FeSO}_{4} \cdot 7 \mathrm{H}_{2} \mathrm{O}, 0.1 \mathrm{~g}$ $\mathrm{NaCl}, 20 \mathrm{~g}$ agar, $1 \%$ used lubricating oil in $1000 \mathrm{~mL}$ distilled water, $\mathrm{pH}$ 7.4). Triplicate plates were incubated at $30^{\circ} \mathrm{C}$ for 5 days before the colonies were counted and randomly picked; pure isolates were obtained by repeated subculturing on nutrient agar (Oxoid). The bacterial isolates were characterized using microscopic techniques and biochemical tests and further confirmed by using API 20NE for Gram-negative bacteria, and BBL Crystal rapid identification kit for Grampositive bacteria. For Gram-positive bacterial identification, colonies of pure culture of bacteria were introduced into the BBL inoculums fluid with the aid of sterile wire loop and vortexed for 10-15 seconds. The turbidity was adjusted to the equivalent of McFarland no. 0.5 standard; the entire inoculum was poured into the BBL base that contains different wells. The inoculum was gently rolled with both hands to ensure that all the wells are filled. The wells containing the inoculums were later covered with BBL lid that contained 29 dehydrated biochemical and enzymatic substrates and a fluorescence control on tips of plastic prongs. The inoculated panels were incubated for $18-24$ hours at $35-37^{\circ} \mathrm{C}$; at the end of incubation period the wells were examined for 
TABLE 1: Physicochemical properties of soil and organic wastes used for bioremediation.

\begin{tabular}{|c|c|c|c|c|}
\hline \multirow{2}{*}{ Parameter } & \multirow{2}{*}{ Soil } & \multicolumn{3}{|c|}{ Organic wastes } \\
\hline & & BSG & BS & SMC \\
\hline $\mathrm{pH}$ & $6.12 \pm 0.23$ & $6.66 \pm 0.49$ & $7.04 \pm 0.29$ & $5.64 \pm 0.25$ \\
\hline Nitrogen $(\%)$ & $0.4 \pm 0.02$ & $1.02 \pm 0.1$ & $0.4 \pm 0.01$ & $0.5 \pm 0.03$ \\
\hline Phosphorus (mg/kg) & $21.8 \pm 1.5$ & $20.6 \pm 2.0$ & $21.2 \pm 1.4$ & $22.5 \pm 1.8$ \\
\hline Organic C (\%) & $10.3 \pm 1.1$ & $10.9 \pm 0.91$ & $10.5 \pm 1.3$ & $10.2 \pm 1.1$ \\
\hline Moisture (\%) & $7.0 \pm 0.3$ & $71.84 \pm 3.5$ & $38.5 \pm 2.86$ & $62.3 \pm 4.12$ \\
\hline Sand $(\%)$ & $37.5 \pm 2.6$ & - & - & - \\
\hline Silt (\%) & $18.75 \pm 1.95$ & - & - & - \\
\hline Clay $(\%)$ & $43.75 \pm 2.75$ & - & - & - \\
\hline HUB (CFU/g) & $6.2 \times 10^{3}$ & $7.4 \times 10^{2}$ & $2.1 \times 10^{2}$ & $4.5 \times 10^{2}$ \\
\hline Texture & Clayey & - & - & - \\
\hline
\end{tabular}

BSG: Brewery spent grain, BS: banana skin, SMC: spent mushroom compost, HUB: hydrocarbon utilizing bacteria.

colour change or presence of fluorescence that resulted from metabolic activities of the microorganisms. The resulting patterns of the 29 reactions were converted into a ten-digit profile number that were used as the basis for identification. The resulting profile number derived from different colour changes and cell morphology were entered into PC in which the BBL Crystal MIND Software has been installed to obtain the bacterial identification.

Gram-negative bacterial isolates were identified using API 20 NE. Pure culture colonies of bacterial sample were transferred into an ampoule of $\mathrm{API} \mathrm{NaCl} 0.85 \%$ medium $(2 \mathrm{~mL})$ with the aid of inoculating wire loop to prepare a suspension with a turbidity equivalent to $0.5 \mathrm{McFarland}$ standard. Tests of $\mathrm{NO}_{3}$ to PNPG in the API panel were inoculated by distributing the saline suspension into the tubes using sterile pipette. $200 \mu \mathrm{L}$ of the remaining suspension was added into an ampoule of API AUX medium and homogenized. The cupules tests GLU to PAC were filled with the suspension from API AUX medium followed by addition of mineral oil to the test cupule-labeled GLU, ADH, and URE until a convex meniscus was formed. The incubation box was closed and incubated at $29^{\circ} \mathrm{C} \pm 2{ }^{\circ} \mathrm{C}$. At the end of the incubation period, the results were read based on colour changes and converted into numerical profile. The identification was performed by using the database (V7.0) with the analytical profile index which was earlier installed into the PC.

2.6. Germination Toxicity Test of Remediated Soil. Toxicity of the remediated soils was assessed using germination test. Lettuce was used in this study owing to its sensitivity to hydrocarbon in soil $[24,25]$. The germination test was conducted over a 5-day test period. Seeds of lettuce were obtained commercially. For each soil sample, $150 \mathrm{~g}$ of thoroughly mixed remediated soil was placed in $100 \times$ $15 \mathrm{~mm}$ Petri dish. Ten viable seeds of lettuce (Lactuca sativa L.) were placed evenly throughout each petri dish and covered with $10 \mathrm{~g}$ of dry sand. Three replicates of the samples were prepared. The moisture of the soil was maintained at $80 \%$ water holding capacity. The Petri dishes were placed in a room with 16 hours light and 8 hours darkness for 5 days.
At the end of 5 days, the number of seedlings that emerged from the surface of the sand was counted and recorded.

Germination index of lettuce seed on the remediated soil was calculated using the formula of Millioli et al. [26]:

$$
\begin{gathered}
\text { Germination index }(\%)=\frac{(\% \mathrm{SG}) \times(\% \mathrm{GR})}{100}, \\
\% \mathrm{SG}=(\% \mathrm{EG} / \% \mathrm{CG}) \times 100 \\
\% \mathrm{GR}=(\mathrm{GERm} / \mathrm{GERCm}) \times 100,
\end{gathered}
$$

where $\%$ SG $=$ seed germination, $\%$ GR = growth of the root, $\% \mathrm{EG}=$ germination on contaminated soil, $\% \mathrm{CG}=$ germination on control soil, GERm = elongation of root on contaminated soil, GERCm = elongation of root on control soil.

2.7. Statistical Analysis. Statistical analysis of data was carried out using Analysis of Variance (ANOVA).

\section{Results and Discussion}

3.1. Physicochemical Properties of Soil and Organic Wastes. The physicochemical properties of soil and organic wastes used for the bioremediation studies are shown in Table 1 . The soil used for bioremediation had $\mathrm{C}: \mathrm{N}$ ratio of 25.7; this is a low $\mathrm{C}: \mathrm{N}$ ratio for effective biodegradation of oil in the soil, hence the need for addition of organic wastes as a source of nutrients ( $\mathrm{N}$ and P). BSG had the highest $\mathrm{N}$ content among the three organic wastes used; this is one of the most important limiting nutrient for effective bioremediation to take place $[27,28]$. The moisture contents of BSG $(71.8 \%)$ were as well higher than those of BS (38.5\%) and $(62.3 \%)$; this might enable the BSG to harbor some important microorganisms that will contribute positively to the biodegradation of oil in the soil. The $\mathrm{pH}$ of SMC (5.6) was slightly acidic; the reason for this might be because it was used to grow fungi (mushroom) which grow better in an acidic environment. Therefore, the initial substrate of SMC might be slightly acidic in nature. 
3.2. Biodegradation of Used Lubricating Oil. The percentage of oil biodegradation in the soil contaminated with 5\% and 15\% used lubricating oil is shown in Figures 1 and 2, respectively. The results revealed rapid and high (between $79 \%$ and $92 \%$ ) biodegradation of the used lubricating oil at the end of 84 days in soil contaminated with $5 \%$ oil. Soil amended with different organic wastes recorded the highest rate of oil mineralization compared to unamended polluted soil. The reason for this relatively high and progressive biodegradation in all the soil contaminated with $5 \%$ used lubricating oil might be due to low concentration of oil in the soil which does not pose serious challenge to the metabolic activities of soil microrganisms. It could also be due to the presence of organic waste amendments which likely supply nutrient to the microbial population present in the contaminated soil, thereby enabling them to degrade almost completely the oil contaminant. The result is in agreement with the findings of Rahman et al. [21] who reported increase in the rate of biodegradation of crude oil, as the concentration of oil reduced.

At the end of 28 days in soil contaminated with $15 \%$ oil, there were $17 \%, 24 \%$, and $5 \%$ total petroleum hydrocarbon (TPH) degradation in soil amended with BSG, BS, and SMC, respectively. The reason for the low percentage of oil degradation within the first 28 days might be attributed to the toxicity of the oil on the microbial flora of the soil, due to high concentration of oil which might likely had negative effects on the biodegradative activities of the microbial population in the contaminated soil. This initial trend of low biodegradation due to high oil concentration has been reported by different authors $[20,21]$ who argued that high concentration of hydrocarbon can be inhibitory at the initial stage to the indigenous microorganisms in the soil. At the end of 84 days, $55 \%, 49 \%$, and $36 \%$ oil biodegradation were recorded in soil contaminated with $15 \%$ oil amended with BSG, BS, and SMC, respectively. In soil contaminated with $5 \%$ oil, $92 \%$ oil biodegradation was recorded in soil amended with BSG, followed by $84 \%$ degradation in soil treated with BS, and $79 \%$ in soil amended with SMC at the end of 84 days. The results are in contrast with the findings of Adesodun and Mbagwu [22] who reported 30\% and $42 \%$ biodegradation in soil contaminated with $5 \%$ spent lubricating oil and amended with cow dung and piggery wastes within the period of three months. The differences in these results might be due to different composition of used lubricating oil utilized for the studies or differences in the organic wastes used. It might as well be due to differences in the soil composition used for the studies.

BSG-amended soil recorded highest percentage biodegradation ( $92 \%$ and $55 \%$ ) throughout the 84 days period in $5 \%$ and $15 \%$ oil-contaminated soil, respectively. This might be due to high $\mathrm{N}$ and $\mathrm{P}$ contents present in BSG. $\mathrm{N}$ and $\mathrm{P}$ are known as the most important nutrients needed by hydrocarbon-utilizing bacteria to carry out effective and efficient biodegradative activities of xenobiotics in the soil environment [27-29]. $8 \%$ and $5 \%$ of oil degradation in $5 \%$ and $15 \%$ oil-polluted soil might be due to nonbiological factors such as evaporation or photodegradation. This was recorded in poisoned controlled soil, that is, autoclaved contaminated

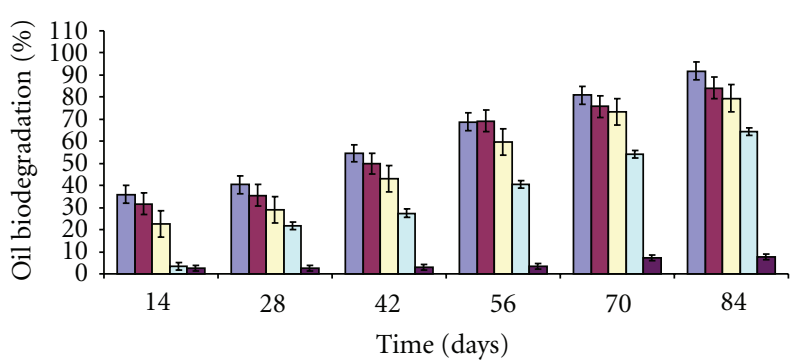

․ Soil $+5 \%$ oil $+10 \%$ BSG a Autoclaved soil $+5 \%$ oil

口 Soil $+5 \%$ oil only $\quad$ Soil $+5 \%$ oil $+10 \%$ SMC

- Soil $+5 \%$ oil $+10 \%$ BS

FIGURE 1: Biodegradation of petroleum hydrocarbon in soil contaminated with $5 \%$ used lubricating oil and amended with $10 \%$ organic wastes.

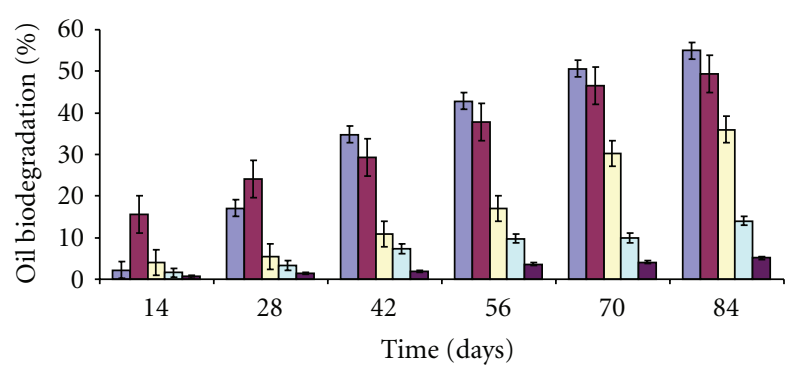

$$
\begin{array}{ll}
\text { - Soil }+15 \% \text { oil }+10 \% \text { BSG } & \text { Autoclaved soil }+15 \% \text { oil } \\
\text { - Soil }+15 \% \text { oil only } & \text { - Soil }+15 \% \text { oil }+10 \% \text { SMC } \\
\text { - Soil }+15 \% \text { oil }+10 \% \text { BS } &
\end{array}
$$

FIGURE 2: Biodegradation of petroleum hydrocarbon in soil contaminated with $15 \%$ used lubricating oil and amended with $10 \%$ organic wastes.

soil treated with $0.5 \%$ sodium azide. This was in sharp contrast to the findings of Palmroth et al. [30], who recorded as high as $70 \%$ diesel oil loss within 28 days of study in sodium azide-treated soil. The differences in these results might be because poisoned control in this study was an autoclaved soil mixed with $0.5 \%$ sodium azide, whereas Palmroth et al. [30] used only $0.5 \%$ sodium azide without autoclaving the soil; thus the sodium azide effect possibly could not completely sterilize the soil.

3.3. Biodegradation Rate. First-order kinetics was used to determine the rate of biodegradation of used lubricating oil in the various treatments as shown in Table 2 . In soil contaminated with 5\% used lubricating oil, BSG-amended soil recorded the highest biodegradation rate of 0.4361 day $^{-1}$. The biodegradation rates of soil amended with BS and SMC were $0.410 \mathrm{day}^{-1}$ and $0.3100 \mathrm{day}^{-1}$, respectively. Unamended and autoclaved contaminated soil recorded biodegradation rates of $0.1886 \mathrm{day}^{-1}$ and $0.0079 \mathrm{day}^{-1}$, respectively. However, in $15 \%$ used lubricating-oil-contaminated soil, BS-amended soil recorded highest biodegradation rate of $0.0556 \mathrm{day}^{-1}$. The biodegradation rates of soil amended with BSG and SMC were 0.0479 day $^{-1}$ and 0.0216 day $^{-1}$, respectively. High biodegradation rate recorded in BS-amended 
TABLE 2: Biodegradation rates of hydrocarbon in used lubricatingoil-contaminated soil.

\begin{tabular}{lc}
\hline Treatment & Biodegradation constant $(k)$ day $^{-1}$ \\
\hline Soil $+5 \%$ oil + BS & $0.4010^{\mathrm{b}}$ \\
Soil $+5 \%$ oil + BSG & $0.4361^{\mathrm{b}}$ \\
Soil $+5 \%$ oil + SMC & $0.3100^{\mathrm{b}}$ \\
Soil $+5 \%$ oil & $0.1886^{\mathrm{a}}$ \\
Autoclaved soil $+5 \%$ oil & $0.0079^{\mathrm{a}}$ \\
Soil $+15 \%$ oil + BS & $0.0556^{\mathrm{b}}$ \\
Soil $+15 \%$ oil + BSG & $0.0479^{\mathrm{a}}$ \\
Soil $+15 \%$ oil + SMC & $0.0216^{\mathrm{b}}$ \\
Soil $+15 \%$ oil & $0.0092^{\mathrm{a}}$ \\
Autoclaved soil $+15 \%$ oil & $0.0033^{\mathrm{a}}$ \\
\hline
\end{tabular}

Values followed by letter $\mathrm{b}$ indicate significant difference at $P<0.05$ level, while values followed by "a" are not different significantly at $P<0.05$ level.

soil above that of BSG might be due to initial rapid loss of used lubricating oil in the first 28 days of study in BSamended soil than those of BSG- and SMC-amended soil. This is however different from the results of Adesodun and Mbagwu [22], who reported highest biodegradation rate in oil-contaminated soil amended with piggery wastes, which had highest percentage of biodegradation throughout the study period.

The results show significant relationships between the rate of biodegradation and concentration of oil in the contaminated soil. From the results, higher biodegradation rates were recorded in soil contaminated with $5 \%$ oil; this high biodegradation rate could be attributed to increase in the activity of soil microbes in this oil pollution level [22]. Bossert and Bartha [31] stated that sensitivity of soil microflora to petroleum hydrocarbons is a factor of quantity and quality of oil spilled and previous exposure of the native soil microbes to oil. Schaefer and Juliane [32] also concluded that bioremediation is a useful method of soil remediation if pollutant concentrations are moderate.

3.4. Microbial Counts. Count of hydrocarbon utilizing bacteria (HUB) in soil contaminated with 5\% used lubricating oil and amended with organic wastes is shown in Figure 3. The count of HUB in soil amended with BSG was about $8 \%$ higher than those amended with BS and SMC. HUB count in BSG amended soil ranged from $47.0 \times 10^{6} \mathrm{CFU} / \mathrm{g}$ to $146.0 \times 10^{6} \mathrm{CFU} / \mathrm{g}$ while those amended with BS and SMC ranged from $42 \times 10^{6} \mathrm{CFU} / \mathrm{g}$ to $120 \times 10^{6} \mathrm{CFU} / \mathrm{g}$ and $12.0 \times$ $10^{6} \mathrm{CFU} / \mathrm{g}$ to $51.0 \times 10^{6} \mathrm{CFU} / \mathrm{g}$, respectively, within 84 days of study. The count of HUB in $15 \%$ used lubricating-oilcontaminated soil amended with BSG was about 3\% higher than those amended with BS and SMC. HUB count in BSGamended soil ranged from $24.0 \times 10^{5} \mathrm{CFU} / \mathrm{g}$ to $210.0 \times$ $10^{5} \mathrm{CFU} / \mathrm{g}$, while those amended with BS and SMC ranged from $15.0 \times 10^{5} \mathrm{CFU} / \mathrm{g}$ to $167 \times 10^{5} \mathrm{CFU} / \mathrm{g}$, and $3.0 \times$ $10^{5} \mathrm{CFU} / \mathrm{g}$ and $38.0 \times 10^{5} \mathrm{CFU} / \mathrm{g}$ respectively (Figure 4 ). However, the HUB count in unamended control soil was extremely $\left(2.0 \times 10^{5} \mathrm{CFU} / \mathrm{g}\right.$ to $\left.14.0 \times 10^{5} \mathrm{CFU} / \mathrm{g}\right)$ lower than those amended with organic wastes.

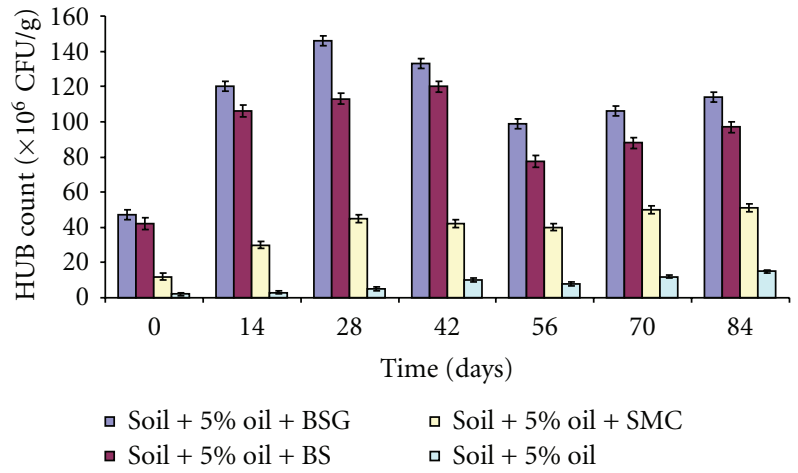

Figure 3: Hydrocarbon-utilizing bacteria (HUB) in soil contaminated with $5 \%$ used lubricating oil and amended with organic wastes.

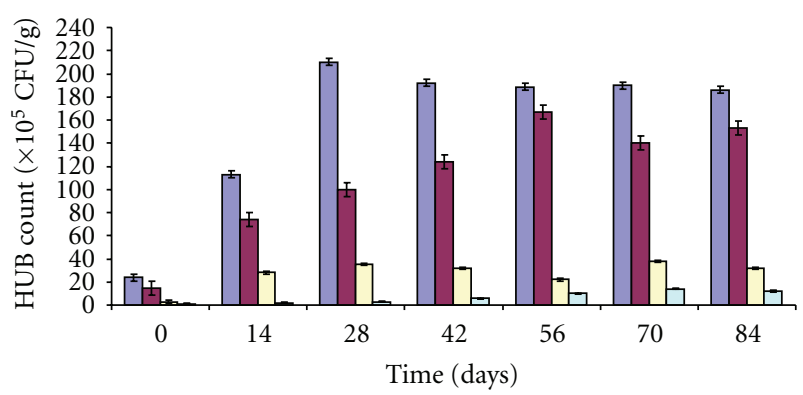

Soil $+15 \%$ oil $+10 \%$ BSG Soil $+15 \%$ oil $+10 \%$ SMC

- Soil $+15 \%$ oil $+10 \%$ BS a Soil $+15 \%$ oil

FIgure 4: Hydrocarbon-utilizing bacteria (HUB) in soil contaminated with $15 \%$ used lubricating oil and amended with organic wastes.

The counts of hydrocarbon utilizing bacteria (HUB) in all the soil amended with organic wastes were appreciably higher compared to those of unamended and poisoned control soil. The reason for higher counts of bacteria in amended soil might be as a result of presence of appreciable quantities of nitrogen and phosphorus in the organic wastes, especially high nitrogen content in BSG, which are necessary nutrients for bacterial biodegradative activities [20, 22, 33-35]. The reason for increased biodegradation of oil in amended soil as compared to the unamended soil might also be due to the presence of organic wastes in the soil which helps to loosen the compactness of the soil making sufficient aeration available for the indigenous bacteria present in the soil, thereby enhancing their metabolic activities in the contaminated soil. It might as well be due to the ability of these organic wastes (mostly BSG that recorded higher counts) to neutralize the toxic effects of the oil on the microbial population by rapid improvement of the soil physicochemical properties [16].

The HUB isolated from the used lubricating-oil-contaminated soil were identified as species of Acinetobacter, Micrococcus, Pseudomonas aeruginosa, Nocardia, Bacillus mega-terium, Bacillus sp., and Corynebacterium. These bacterial species had been implicated in hydrocarbon degradation by different authors $[9,36-40]$. 
TABLE 3: Toxicity test based on seed germination (\%).

\begin{tabular}{lcccccc}
\hline $\begin{array}{c}\text { Percentage of } \\
\text { Oil pollution }\end{array}$ & A & B & C & D & E & F \\
\hline 5 & $80 \pm 6.0$ & 100 & $80 \pm 6.0$ & $40 \pm 6.0$ & $20 \pm 0$ & 100 \\
15 & $40 \pm 5.8$ & $40 \pm 6.0$ & $20 \pm 0$ & $10 \pm 0$ & 0 & 100
\end{tabular}

$\mathrm{A}=$ Soil + Oil + BS, B = Soil + Oil + BSG, C = Soil + Oil + SMC, D = Soil + Oil, $\mathrm{E}=$ Autoclaved soil + Oil $+\mathrm{NaN}_{3}, \mathrm{~F}=$ Uncontaminated soil.

TABLE 4: Seed germination toxicity index (\%).

\begin{tabular}{lccccc}
\hline Percentage of & \multicolumn{5}{c}{ Germination toxicity index (\%) } \\
Oil pollution & A & B & C & D & E \\
\hline 5 & 40.00 & 83.33 & 33.34 & 13.33 & 3.27 \\
15 & 6.53 & 13.33 & 5.00 & 1.65 & 0.00 \\
\hline
\end{tabular}

$\mathrm{A}=$ Soil + Oil + BS, B = Soil + Oil + BSG, C = Soil + Oil + SMC, D = Soil + Oil, $\mathrm{E}=$ Autoclaved soil + Oil $+\mathrm{NaN}_{3}$.

3.5. Germination Toxicity. Lettuce (Lactuca sativa) is an important agricultural crop, and it is fairly sensitive to toxic chemicals (mostly petroleum contaminants), which led to its wide use for toxicity tests $[41,42]$. The results of germination toxicity test conducted after 84 days of remediation for soil contaminated with 5\% and 15\% used lubricating oil and amended organic wastes are shown in Table 3. The results reveal $100 \%, 80 \%$, and $80 \%$ germination in soil contaminated with $5 \%$ oil and amended with BSG, BS, and SMC, respectively. However, 40\%, 40\%, and 20\% seed germination were recorded in soil contaminated with $15 \%$ oil and amended with BSG, BS, and SMC, respectively. $100 \%$ germination was recorded in uncontaminated control soil, while only $20 \%$ and $0 \%$ were recorded in poisoned controlled soil in soil contaminated with $5 \%$ and $15 \%$ used lubricating oil, respectively. The result shows positive correlation between loss of oil in the remediated soil and seed germination. It also revealed that remediation of soil contaminated with high concentration of petroleum hydrocarbons needs a longer period of time possibly with increased quantity of organic wastes amendment to be completely restored into a state suitable for agricultural purposes. The results are in agreement with the findings of Banks and Schultz [41] and Millioli et al. [26], who recorded decrease in number of germinated seeds with increased quantities of petroleum concentration in the soil.

3.6. Seed Germination Index. Germination index of lettuce seed on the remediated soil was calculated using the formula of Millioli et al. [26]. Table 4 shows the results of seed germination index in soil contaminated with $15 \%$ and $5 \%$ used lubricating oil and amended with different organic wastes. Soil treated with BSG recorded the highest germination index $(83.33 \%, \& 13.33 \%)$ in all the treatments with organic wastes amendments; this result further proved the effectiveness of BSG in enhancing biodegradation of hydrocarbon in oil-contaminated soil. The result is similar to the finding of Molina-Barahona et al. [43] and Oleszczuk [42], who reported that composted wastewater sludge reduced phytotoxicity of diesel oil to the germination of Lepidium sativum after composting the sludge for 76 days. The negative effect of hydrocarbons on the germination index may be attributed to their inherent toxicity or to the perturbations they cause in soil and plants due to their hydrophobic properties $[44,45]$. Hydrocarbons may coat root surface, preventing or reducing gas and water exchange and nutrient absorption. They may also enter the seeds and alter the metabolic reactions or kill the embryo by direct, acute toxicity after penetrating the plant tissues. Hydrocarbons damage cell membranes and reduce the metabolic transport and respiration rate $[44,46]$. But, a more likely reason for the inhibitory effect of hydrocarbons on germination is its physical water-repellent property. The film of hydrocarbons around the seeds may act as a physical barrier, preventing or reducing both water and oxygen from entering the seeds. This would inhibit the germination response [44].

\section{Conclusion}

Amendment of soil contaminated with used lubricating oil with organic wastes positively enhanced the rate of biodegradation of used lubricating oil in soil within the period of 84 days. The results of the studies in soil contaminated with $5 \%$ and $15 \%$ used lubricating oil amended with organic wastes (BS, BSG, and SMC) show low (55\%) oil biodegradation in soil contaminated with $15 \%$ oil compared with $92 \%$ oil biodegradation recorded in $5 \%$ oil pollution, thus, showing that level of oil contamination influenced the rate of oil biodegradation in soil environment. Contaminated soil amended with BSG recorded highest rate of oil biodegradation and counts of hydrocarbon utilizing bacteria compared to soil amended with BS and SMC in both 5\% and $15 \%$ oil pollution. Results of germination toxicity test carried out on the remediated soil showed less toxicity to lettuce in $5 \%$ oil-contaminated soil compared to those of $15 \%$ oilcontaminated soil. Therefore, brewery spent grain, which is a waste from brewery, can be utilized effectively to reclaim soil contaminated with used lubricating oil.

\section{Acknowledgments}

The authors would like to acknowledge the support of University of Malaya, IPPP grant PS 244/2008C, and FRGS Grant FP014/2010A. Also, they would like to thank the management of the Carlsberg Brewery for providing brewery spent grain and the Ganofarm Sdn. Bhd for the provision of spent mushroom compost.

\section{References}

[1] T. Mandri and J. Lin, "Isolation and characterization of engine oil degrading indigenous microorganisms in Kwazulu-Natal," African Journal of Biotechnology, vol. 6, no. 1, pp. 23-27, 2007.

[2] A. Husaini, H. A. Roslan, K. S. Y. Hii, and C. H. Ang, "Biodegradation of aliphatic hydrocarbon by indigenous fungi isolated from used motor oil contaminated sites," World Journal of Microbiology and Biotechnology, vol. 24, no. 12, pp. 2789-2797, 2008. 
[3] J. A. Bumpus, "Biodegradation of polycyclic aromatic hydrocarbons by Phanerochaete chrysosporium," Applied and Environmental Microbiology, vol. 55, no. 1, pp. 154-158, 1989.

[4] A. R. Clemente, T. A. Anazawa, and L. R. Durrant, "Biodegradation of polycyclic aromatic hydrocarbons by soil fungi," Brazilian Journal of Microbiology, vol. 32, no. 4, pp. 255-261, 2001.

[5] C. E. Cerniglia and J. B. Sutherland, "Bioremediation of polycyclic aromatic hydrocarbons by ligninolytic and non-ligninolytic fungi," in Fungi in Bioremediation, G. M. Gadd, Ed., pp. 136-187, Cambridge University Press, Cambridge, UK, 2001.

[6] S. Mishra, J. Jyot, R. C. Kuhad, and B. Lal, "Evaluation of inoculum addition to stimulate in situ bioremediation of oily-sludge-contaminated soil," Applied and Environmental Microbiology, vol. 67, no. 4, pp. 1675-1681, 2001.

[7] T. L. Propst, R. L. Lochmiller, C. W. Qualls, and K. McBee, "In situ (mesocosm) assessment of immunotoxicity risks to small mammals inhabiting petrochemical waste sites," Chemosphere, vol. 38, no. 5, pp. 1049-1067, 1999.

[8] A. C. Lloyd and T. A. Cackette, "Diesel engines: environmental impact and control," Journal of the Air and Waste Management Association, vol. 51, no. 6, pp. 809-847, 2001.

[9] J. D. Van Hamme, A. Singh, and O. P. Ward, "Recent advances in petroleum microbiology," Microbiology and Molecular Biology Reviews, vol. 67, no. 4, pp. 503-549, 2003.

[10] W. C. Blodgett, "Water-soluble mutagen production during the bio-remediation of oil-contaminated soil," Florida Scientist, vol. 60, no. 1, pp. 28-36, 2001.

[11] L. S. Hagwell, L. M. Delfino, and J. J. Rao, "Partitioning of polycyclic aromatic hydrocarbons from diesel fuel into water," Environmental Science and Technology, vol. 26, no. 11, pp. 2104-2110, 1992.

[12] S. Boonchan, M. L. Britz, and G. A. Stanley, "Degradation and mineralization of high-molecular-weight polycyclic aromatic hydrocarbons by defined fungal-bacterial cocultures," Applied and Environmental Microbiology, vol. 66, no. 3, pp. 1007-1019, 2000.

[13] J. Hollender, K. Althoff, M. Mundt, and W. Dott, "Assessing the microbial activity of soil samples, its nutrient limitation and toxic effects of contaminants using a simple respiration test," Chemosphere, vol. 53, no. 3, pp. 269-275, 2003.

[14] K. T. Semple, N. M. Dew, K. J. Doick, and A. H. Rhodes, "Can microbial mineralization be used to estimate microbial availability of organic contaminants in soil?" Environmental Pollution, vol. 140, no. 1, pp. 164-172, 2006.

[15] J. Walworth, A. Pond, I. Snape, J. Rayner, S. Ferguson, and P. Harvey, "Nitrogen requirements for maximizing petroleum bioremediation in a sub-Antarctic soil," Cold Regions Science and Technology, vol. 48, no. 2, pp. 84-91, 2007.

[16] K. S. Jørgensen, J. Puustinen, and A. M. Suortti, "Bioremediation of petroleum hydrocarbon-contaminated soil by composting in biopiles," Environmental Pollution, vol. 107, no. 2, pp. 245-254, 2000.

[17] R. Margesin and F. Schinner, "Bioremediation (Natural Attenuation and Biostimulation) of diesel-oil-contaminated soil in an alpine glacier skiing area," Applied and Environmental Microbiology, vol. 67, no. 7, pp. 3127-3133, 2001.

[18] R. Riffaldi, R. Levi-Minzi, R. Cardelli, S. Palumbo, and A. Saviozzi, "Soil biological activities in monitoring the bioremediation of diesel oil-contaminated soil," Water, Air, and Soil Pollution, vol. 170, no. 1-4, pp. 3-15, 2006.

[19] R. Margesin, M. Hämmerle, and D. Tscherko, "Microbial activity and community composition during bioremediation of diesel-oil-contaminated soil: effects of hydrocarbon concentration, fertilizers, and incubation time," Microbial Ecology, vol. 53, no. 2, pp. 259-269, 2007.

[20] U. J. J. Ijah and S. P. Antai, "The potential use of chicken-drop micro-organisms for oil spill remediation," Environmentalist, vol. 23, no. 1, pp. 89-95, 2003.

[21] K. S. M. Rahman, J. Thahira-Rahman, P. Lakshmanaperumalsamy, and I. M. Banat, "Towards efficient crude oil degradation by a mixed bacterial consortium," Bioresource Technology, vol. 85, no. 3, pp. 257-261, 2002.

[22] J. K. Adesodun and J. S. C. Mbagwu, "Biodegradation of waste-lubricating petroleum oil in a tropical alfisol as mediated by animal droppings," Bioresource Technology, vol. 99, no. 13, pp. 5659-5665, 2008.

[23] J. E. Zajic and B. Supplisson, "Emulsification and degradation of "Bunker C" fuel oil by microorganisms," Biotechnology and Bioengineering, vol. 14, no. 3, pp. 331-343, 1972.

[24] K. Vaajasaari, A. Joutti, E. Schultz, S. Selonen, and H. Westerholm, "Comparisons of terrestrial and aquatic bioassays for oil-contaminated soil toxicity," Journal of Soils and Sediments, vol. 2, no. 4, pp. 194-202, 2002.

[25] G. Płaza, G. Nałęcz-Jawecki, K. Ulfig, and R. L. Brigmon, “The application of bioassays as indicators of petroleum-contaminated soil remediation," Chemosphere, vol. 59, no. 2, pp. 289296, 2005.

[26] V. S. Millioli, E. L. C. Servulo, L. G. S. Sobral, and D. D. Carvalho, "Bioremediation of crude oil-bearing soil: evaluating the effect of rhamnolipid addition to soil toxicity and to crude oil biodegradation efficiency," Global Nest Journal, vol. 11, no. 2, pp. 181-188, 2009.

[27] I. O. Okoh, "Biodegradation alternative in the cleanup of petroleum hydrocarbon pollutants," Biotechnology and Molecular Biology Reviews, vol. 1, no. 2, pp. 38-50, 2006.

[28] S. J. Kim, D. H. Choi, D. S. Sim, and Y. S. Oh, "Evaluation of bioremediation effectiveness on crude oil-contaminated sand," Chemosphere, vol. 59, no. 6, pp. 845-852, 2005.

[29] C. Frederic, P. Emilien, G. Lenaick, and D. Daniel, "Effects of nutrient and temperature on degradation of petroleum hydrocarbons in contaminated sub-Antarctic soil," Chemosphere, vol. 58, no. 10, pp. 1439-1448, 2005.

[30] M. R. T. Palmroth, J. Pichtel, and J. A. Puhakka, "Phytoremediation of subarctic soil contaminated with diesel fuel," Bioresource Technology, vol. 84, no. 3, pp. 221-228, 2002.

[31] I. Bossert and R. Bartha, "The fate of petroleum in soil ecosystems," in Petroleum Microbiology, R. M. Atlas, Ed., Macmillan, New York, NY, USA, 1984.

[32] M. Schaefer and F. Juliane, "The influence of earthworms and organic additives on the biodegradation of oil contaminated soil," Applied Soil Ecology, vol. 36, no. 1, pp. 53-62, 2007.

[33] K. Nakasaki, H. Yaguchi, Y. Sasaki, and H. Kubota, "Effects of $\mathrm{C} / \mathrm{N}$ ratio on thermophilic composting of garbage," Journal of Fermentation and Bioengineering, vol. 73, no. 1, pp. 43-45, 1992.

[34] H. S. Joo, C. G. Phae, and J. Y. Ryu, "Comparison and analysis on characteristics for recycling of multifarious food waste," Journal of KOWREC, vol. 9, pp. 117-124, 2001.

[35] H. S. Joo, M. Shoda, and C. G. Phae, "Degradation of diesel oil in soil using a food waste composting process," Biodegradation, vol. 18, no. 5, pp. 597-605, 2007.

[36] U. J. J. Ijah, "Studies on relative capabilities of bacterial and yeast isolates from tropical soil in degrading crude oil," Waste Management, vol. 18, no. 5, pp. 293-299, 1998.

[37] Y. H. Ahn, J. Sanseverino, and G. S. Sayler, "Analyses of polycyclic aromatic hydrocarbon-degrading bacteria isolated from 
contaminated soils," Biodegradation, vol. 10, no. 2, pp. 149157, 1999.

[38] F. M. Bento, F. A. O. Camargo, B. C. Okeke, and W. T. Frankenberger, "Comparative bioremediation of soils contaminated with diesel oil by natural attenuation, biostimulation and bioaugmentation," Bioresource Technology, vol. 96, no. 9, pp. 1049-1055, 2005.

[39] K. Das and A. K. Mukherjee, "Crude petroleum-oil biodegradation efficiency of Bacillus subtilis and Pseudomonas aeruginosa strains isolated from a petroleum-oil contaminated soil from North-East India," Bioresource Technology, vol. 98, no. 7, pp. 1339-1345, 2007.

[40] A. Roldán-Martín, G. Calva-Calva, N. Rojas-Avelizapa, M. D. Díaz-Cervantes, and R. Rodríguez-Vázquez, "Solid culture amended with small amounts of raw coffee beans for the removal of petroleum hydrocarbon from weathered contaminated soil," International Biodeterioration and Biodegradation, vol. 60 , no. 1, pp. 35-39, 2007.

[41] M. K. Banks and K. E. Schultz, "Comparison of plants for germination toxicity tests in petroleum-contaminated soils," Water, Air, and Soil Pollution, vol. 167, no. 1-4, pp. 211-219, 2005.

[42] P. Oleszczuk, "Phytotoxicity of municipal sewage sludge composts related to physico-chemical properties, PAHs and heavy metals," Ecotoxicology and Environmental Safety, vol. 69, no. 3, pp. 496-505, 2008.

[43] L. Molina-Barahona, L. Vega-Loyo, M. Guerrero et al., "Ecotoxicological evaluation of diesel-contaminated soil before and after a bioremediation process," Environmental Toxicology, vol. 20, no. 1, pp. 100-109, 2005.

[44] G. Adam and H. Duncan, "Influence of diesel fuel on seed germination," Environmental Pollution, vol. 120, no. 2, pp. 363-370, 2002.

[45] I. A. Ogboghodo, E. K. Iruaga, I. O. Osemwota, and J. U. Chokor, "An assessment of the effects of crude oil pollution on soil properties, germination and growth of maize (zea mays) using two crude types-forcadors light and escravos light," Environmental Monitoring and Assessment, vol. 96, no. 1-3, pp. 143-152, 2004.

[46] V. Labud, C. Garcia, and T. Hernandez, "Effect of hydrocarbon pollution on the microbial properties of a sandy and a clay soil," Chemosphere, vol. 66, no. 10, pp. 1863-1871, 2007. 

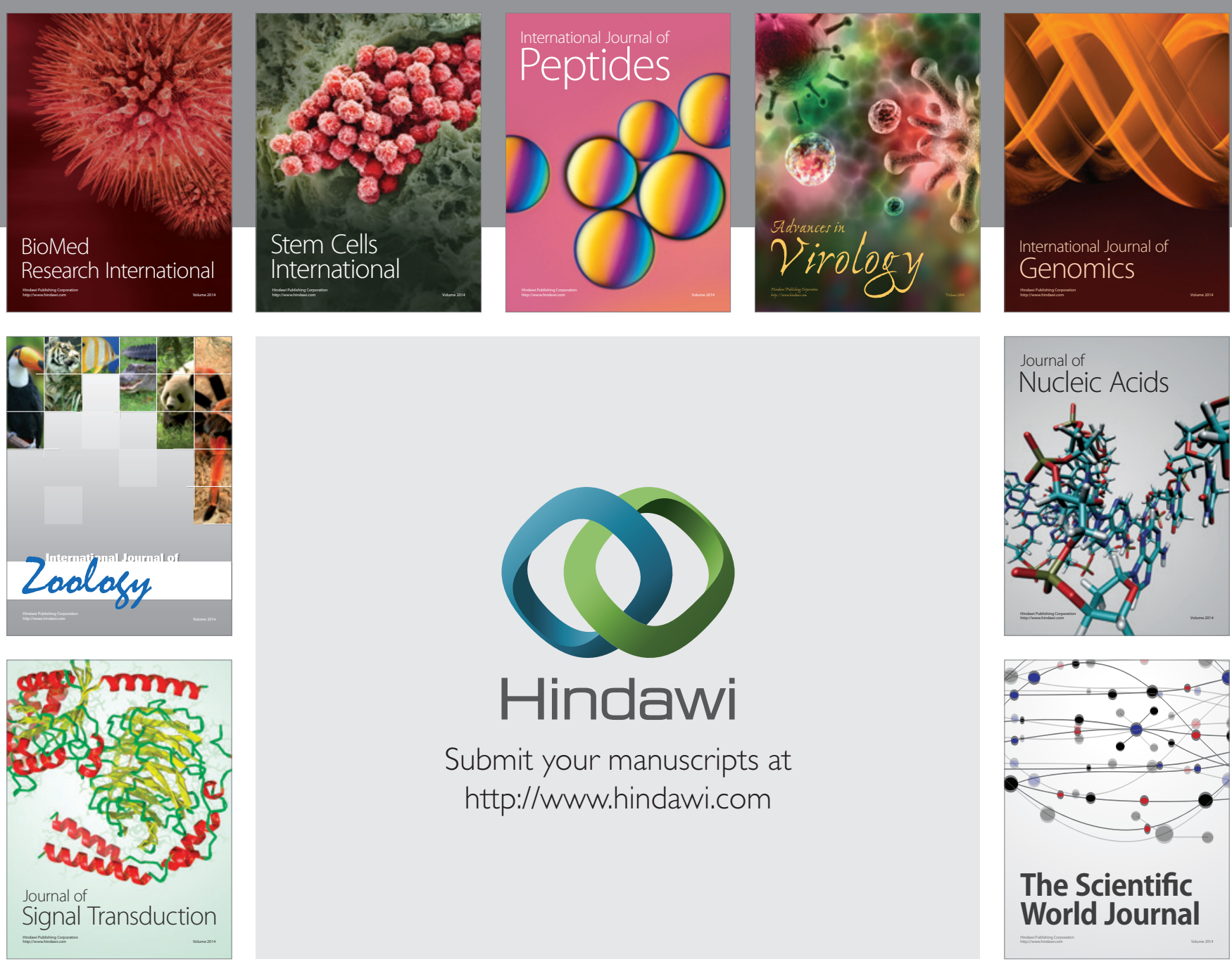

Submit your manuscripts at

http://www.hindawi.com
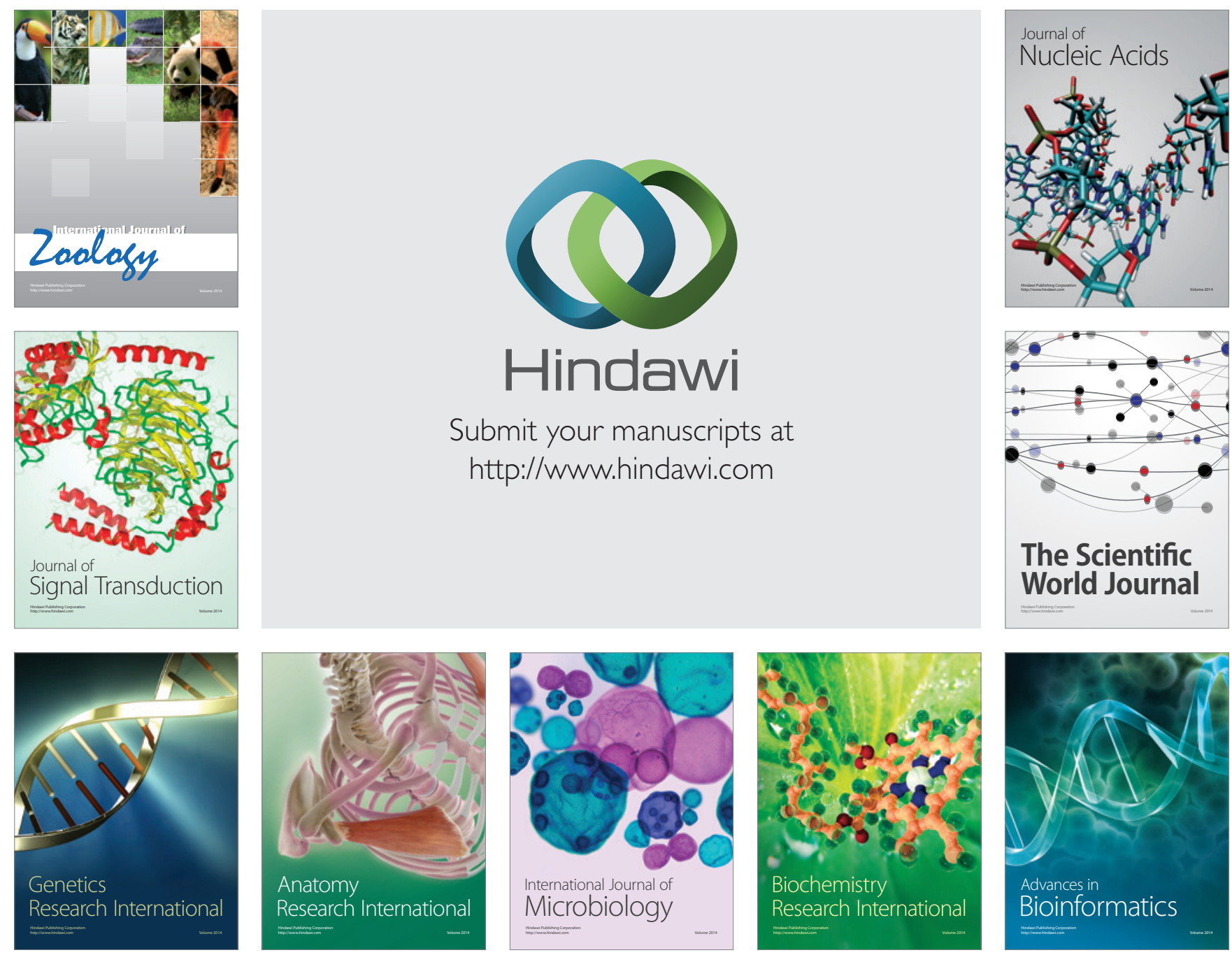

The Scientific World Journal
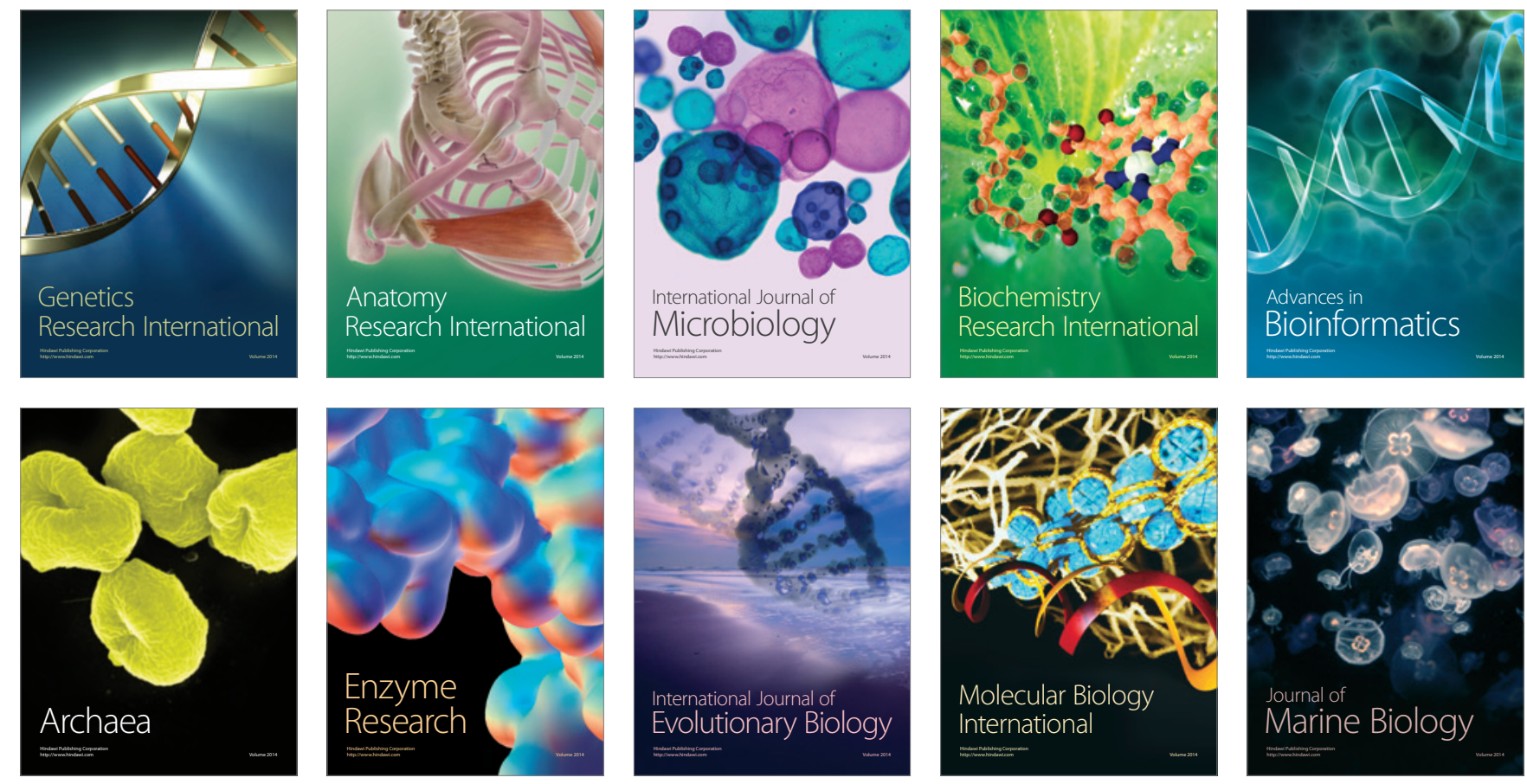